\title{
CANADA IN QUESTION
}

Exploring Our Citizenship in the Twenty-First Century 


\section{Iin UTP insights}

UTP Insights is an innovative collection of brief books offering accessible introductions to the ideas that shape our world. Each volume in the series focuses on a contemporary issue, offering a fresh perspective anchored in scholarship. Spanning a broad range of disciplines in the social sciences and humanities, the books in the UTP Insights series contribute to public discourse and debate and provide a valuable resource for instructors and students.

For a list of books published in the series, see page 121. 


\section{CANADA IN QUESTION}

Exploring Our Citizenship in the Twenty-First Century

Peter MacKinnon

UNIVERSITY OF TORONTO PRESS

Toronto Buffalo London 
(C) University of Toronto Press 2022

Toronto Buffalo London

utorontopress.com

Printed in Canada

ISBN 978-1-4875-4313-6 (cloth)

ISBN 978-1-4875-4315-0 (EPUB)

ISBN 978-1-4875-4314-3 (paper)

ISBN 978-1-4875-4316-7 (PDF)

\section{Library and Archives Canada Cataloguing in Publication}

Title: Canada in question : exploring our citizenship in the twenty-first century / Peter MacKinnon.

Names: MacKinnon, Peter, author.

Series: UTP insights.

Description: Series statement: UTP insights I Includes bibliographical references and index.

Identifiers: Canadiana (print) 20210335556 | Canadiana (ebook)

20210335602 | ISBN 9781487543136 (cloth) | ISBN 9781487543143

(paper) | ISBN 9781487543150 (EPUB) | ISBN 9781487543167 (PDF)

Subjects: LCSH: Citizenship - Canada.

Classification: LCC JL187 .M33 2022 | DDC 323.60971 - dc23

We wish to acknowledge the land on which the University of Toronto Press operates. This land is the traditional territory of the Wendat, the Anishnaabeg, the Haudenosaunee, the Métis, and the Mississaugas of the Credit First Nation.

University of Toronto Press acknowledges the financial support of the Government of Canada, the Canada Council for the Arts, and the Ontario Arts Council, an agency of the Government of Ontario, for its publishing activities.

Canada Council for the Arts
Conseil des Arts du Canada

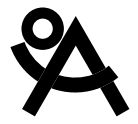

ONTARIO ARTS COUNCIL CONSEIL DES ARTS DE L'ONTARIO

an Ontario government agency

un organisme du gouvernement de l'Ontario

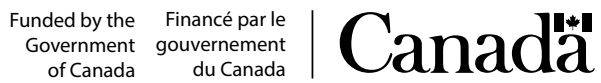


For Canada and Canadians 
This page intentionally left blank 